\title{
Evidence for a Common Binding Cavity for Three General Anesthetics within the GABA Receptor
}

\author{
Andrew Jenkins, ${ }^{1}$ Eric P. Greenblatt, ${ }^{2}$ Howard J. Faulkner, ${ }^{3}$ Edward Bertaccini, ${ }^{4}$ Adam Light, ${ }^{5}$ Audrey Lin, ${ }^{5}$ \\ Alyson Andreasen, ${ }^{1}$ Anna Viner, ${ }^{1}$ James R. Trudell, ${ }^{4}$ and Neil L. Harrison ${ }^{1}$ \\ ${ }^{1}$ C. V. Starr Laboratory for Molecular Neuropharmacology, Department of Anesthesiology, Weill Medical College of Cornell \\ University, New York, New York 10021, 2Department of Anesthesia, University of Pennsylvania School of Medicine, \\ Philadelphia, Pennsylvania 19104, 3/mperial College School of Medicine, London SW7 2AZ, United Kingdom, \\ ${ }^{4}$ Department of Anesthesia, Stanford University School of Medicine, Stanford, California 94305, and 5The University of \\ Chicago, Chicago, Illinois 60637
}

The $\mathrm{GABA}_{\mathrm{A}}$ receptor is an important target for a variety of general anesthetics (Franks and Lieb, 1994) and for benzodiazepines such as diazepam. Specific point mutations in the $\mathrm{GABA}_{\mathrm{A}}$ receptor selectively abolish regulation by benzodiazepines (Rudolph et al., 1999; McKernan et al., 2000) and by anesthetic ethers (Mihic et al., 1997; Krasowski et al., 1998; Koltchine et al., 1999), suggesting the existence of discrete binding sites on the $\mathrm{GABA}_{\mathrm{A}}$ receptor for these drugs. Using anesthetics of different molecular size (isoflurane $>$ halothane $>$ chloroform) together with complementary mutagenesis of specific amino acid side chains, we estimate the volume of a proposed anesthetic binding site as between 250 and $370 \AA^{3}$. The results of the "cutoff" analysis suggest a common site of action for the anesthetics isoflurane, halothane, and chloroform on the $\mathrm{GABA}_{\mathrm{A}}$ receptor. Moreover, the data support a crucial role for Leu232, Ser270, and Ala291 in the $\alpha$ subunit in defining the boundaries of an amphipathic cavity, which can accommodate a variety of small general anesthetic molecules.

Key words: anesthetic; GABA; binding site; allosteric; receptor; molecular volume
Many general anesthetics with simple chemical structures prolong the duration of synaptic inhibition via allosteric regulation of $\mathrm{GABA}_{\mathrm{A}}$ receptors (Jones and Harrison, 1993; Nishikawa and MacIver, 2000). Reciprocal synaptic connections between cortical interneurons can generate high-frequency $(30-60 \mathrm{~Hz})$ oscillatory activity (Jefferys et al., 1996), and entrainment of these local inhibitory microcircuits results in synchronization of these "gamma oscillations" (Whittington et al., 1995). Such high-frequency activity has been linked to cognitive functions such as selective attention (Bragin et al., 1995), and these oscillations are highly sensitive to disruption by central depressants (Faulkner et al., 1998). GABAergic inhibition plays a fundamental role in the timing of these high-frequency oscillations, so that drugs that prolong the time course of synaptic inhibition also decrease the characteristic frequency of these oscillations (Whittington et al., 1996), eventually imposing slow, highamplitude waves in both the EEG and in vitro model systems. Decreases in the EEG spectral edge frequency accompany decrements in cognitive function during the induction of anesthesia (Rampil, 1998). GABA A $_{\mathrm{A}}$ receptors therefore represent one of the major neurobiological substrates for the action of general anesthetics, especially with regard to the ability of these drugs to induce hypnosis and loss of consciousness (Franks and Lieb, 1994).

Inhaled anesthetics alter the function of $\mathrm{GABA}_{\mathrm{A}}$ receptors in acutely dissociated neurons (Nakahiro et al., 1989; Wakamori et

Received Aug. 21, 2000; revised Jan. 10, 2001; accepted Jan. 17, 2001.

This work was supported by National Institutes of Health Grants GM 45129 to N.L.H. and GM 57062 to E.P.G. We thank Peter Goldstein for critical reading of this manuscript and Suzanne Finn and Irene Paraskevakis for mutant cDNAs.

Correspondence should be addressed to Andrew Jenkins, C. V. Starr Laboratory for Molecular Neuropharmacology, Department of Anesthesiology A-1050, Joan and Sanford I. Weill Medical College of Cornell University, 525 East 68th Street, Box 124, New York, NY 10021. E-mail: anj2005@med.cornell.edu.

Copyright (C) 2001 Society for Neuroscience $0270-6474 / 01 / 210001-\bullet \$ 15.00 / 0$ al., 1991; Li and Pearce, 2000) and in heterologous expression systems (Harrison et al., 1993; Mihic et al., 1997; Jenkins et al., 1999). The modulatory action of these inhaled agents, unlike that of diazepam, is independent of the $\gamma$ subunit of the $\mathrm{GABA}_{\mathrm{A}}$ receptor (Harrison et al., 1993; Krasowski et al., 1998; Koltchine et al., 1999). In this study, we have therefore examined the action of these anesthetics on $\mathrm{GABA}_{\mathrm{A}}$ receptors consisting only of $\alpha$ and $\beta$ subunits. $\mathrm{GABA}_{\mathrm{A}}$ receptor modulation by the anesthetic ether isoflurane is abolished by a point mutation at S270 in the TM2 segment of the $\alpha$ subunit (Mihic et al., 1997; Krasowski et al., 1998), whereas the effects of diazepam and other sedative-hypnotic benzodiazepines are abolished by mutating H101 to arginine in the large extracellular N-terminal domain of the $\alpha$ subunit (Rudolph et al., 1999; McKernan et al., 2000). However, although it is known that flunitrazepam binds to H101 but not R101 (Duncalfe et al., 1996), it is not known why S270 permits receptor modulation by isoflurane, whereas an isoleucine residue at this position does not. The present study probes the involvement of S270 and of two other residues in greater detail and extends our analysis of anesthetic action to include the alkanes halothane and chloroform.

This article is published in The Journal of Neuroscience, Rapid Communications Section, which publishes brief, peerreviewed papers online, not in print. Rapid Communications are posted online approximately one month earlier than they would appear if printed. They are listed in the Table of Contents of the next open issue of JNeurosci. Cite this article as: JNeurosci, 2001, 21:RC136 (1-4). The publication date is the date of posting online at www.jneurosci.org.

http://www.jneurosci.org/cgi/content/full/5108 


\section{MATERIALS AND METHODS}

Site-directed mutagenesis and electrophysiology. To create the mutant series at GABA receptor $\alpha 2$ Ser270, mutations were introduced into the cDNA encoding the human $\mathrm{GABA}_{\mathrm{A}}$ receptor $\alpha 2$ subunit at bases 890 to 892, with simultaneous loss of a DdeI restriction site (Koltchine et al., 1999). Additional mutations were created at Ala291 and Leu232 using either the Unique Site Elimination method (Amersham Pharmacia Biotech, Arlington Heights, IL) or a $P f u$ polymerase/DpnI selection method (QuikChange; Stratagene, La Jolla, CA). The sequences of all cDNA inserts were confirmed throughout by double-stranded sequencing. Human embryonic kidney (HEK) 293 cells were maintained in culture on glass coverslips and transfected with cDNAs encoding wild-type or mutant $\alpha 2$ subunits and wild-type $\beta 1$ subunits. Recordings were made using the whole-cell patch-clamp technique as described previously (Koltchine et al., 1999). All drugs and solutions were applied rapidly to the cell by local perfusion using a motor-driven solution exchange device; recordings were made at room temperature $\left(20-22^{\circ} \mathrm{C}\right)$. Bath concentrations of the anesthetics were measured using gas chromatography and represent $90-95 \%$ of the total applied drug concentration. Numerical data are presented throughout as mean \pm SE. Concentrationresponse curves were determined for the wild-type and each mutant $\mathrm{GABA}_{\mathrm{A}}$ receptor (Koltchine et al., 1999). Potentiation of a submaximal GABA response by each anesthetic was then calculated as the percentage increase above the control $\left(\mathrm{EC}_{20}\right)$ response to GABA in the presence of anesthetic (Koltchine et al., 1999).

Molecular volume calculation. Molecules were built in Spartan V5.1 (Wavefunction, San Diego, CA) and optimized with the Merck MMFF94 forcefield. The calculated volumes are van der Waals volumes and are given in $\AA^{3}$.

\section{RESULTS}

\section{Different mutations are required to remove sensitivity to different anesthetics}

The wild-type $\alpha 2 \beta 1 \mathrm{GABA}_{\mathrm{A}}$ receptor is potentiated by isoflurane and halothane (Fig. 1a). The mutant receptor $\alpha 2(\mathrm{~S} 270 \mathrm{H}) \beta 1$ is insensitive to isoflurane (Krasowski et al., 1998) but shows normal sensitivity to the alkane anesthetic halothane (Fig. 1b). This finding initially suggested to us that S270 in TM2 might participate in binding isoflurane, but not halothane. The TM1 segment of the homologous glycine receptor was recently inferred to confer sensitivity to halothane (Greenblatt and Meng, 1999); we subsequently observed that the mutant $\mathrm{GABA}_{\mathrm{A}}$ receptor $\alpha 2(\mathrm{~L} 232 \mathrm{~F}) \beta 1$ was insensitive to halothane, whereas sensitivity to isoflurane remained (Fig. 1c). This finding suggested initially that L232 in TM1 might participate in binding halothane, but not isoflurane, and pointed to the possibility that these two anesthetics might act at different sites on the $\mathrm{GABA}_{\mathrm{A}}$ receptor. However, when a larger Trp residue was introduced at S270, the mutant receptor $\alpha 2(\mathrm{~S} 270 \mathrm{~W}) \beta 1$ was shown to lack sensitivity to halothane, as well as isoflurane (Fig. 1d). Interestingly, this receptor retained sensitivity to a third anesthetic, chloroform (Fig. 1e). Mutation at A291 in TM3 of the $\alpha$ subunit has previously been shown to abolish receptor regulation by isoflurane (Krasowski et al., 1998), and we therefore added a second Trp residue at this position to create the double mutant $\alpha 2$ (S270W; A291W) $\beta 1$ receptor. This receptor was completely insensitive to chloroform (Fig. 1e), isoflurane, and halothane, but retained sensitivity to propofol (data not shown), an anesthetic believed to exert its actions via a site on the $\beta$ subunit (Sanna et al., 1995; Krasowski et al., 1998).

The idea that the three residues (L232, S270, and A291) could be mutated to selectively or completely remove anesthetic modulation was then tested further. The S270W mutation was sufficient to remove isoflurane and halothane sensitivity, whereas the L232F mutation was sufficient to block potentiation by halothane but not isoflurane; in light of these observations, we also mutated L232 to tryptophan. The $\alpha 2(\mathrm{~L} 232 \mathrm{~W}) \beta 1$ receptor expressed at normal levels and, like the $\alpha 2(\mathrm{~S} 270 \mathrm{~W}) \beta 1$ receptor, was insensitive
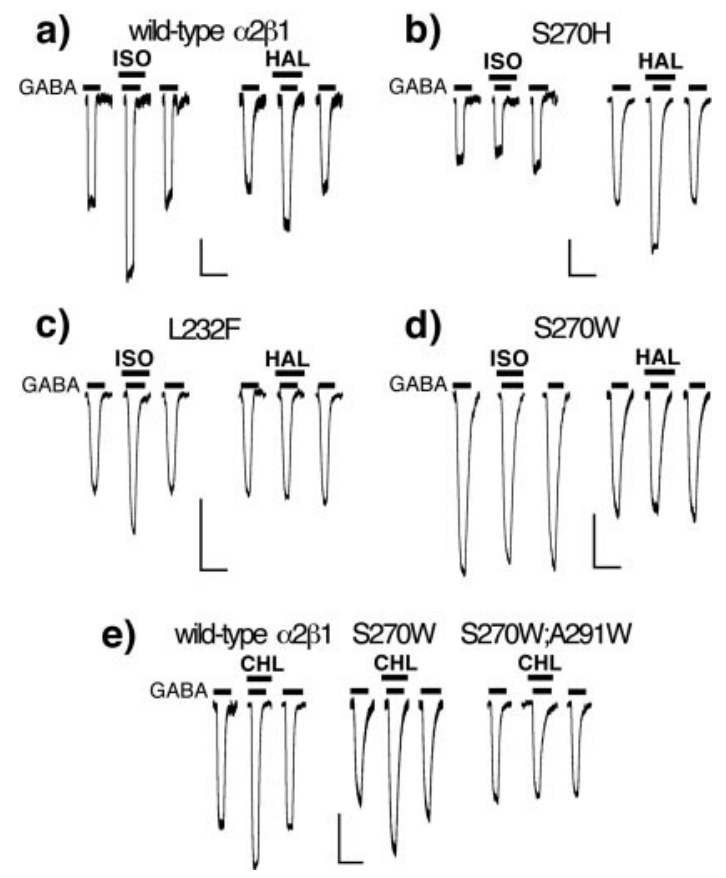

Figure 1. Effects of three general anesthetics on wild-type and mutant $\mathrm{GABA}_{\mathrm{A}}$ receptors. All receptors were expressed in HEK 293 cells and studied using whole-cell voltage-clamp recording at $-60 \mathrm{mV}$ (Krasowski et al., 1998). Currents were activated by $\mathrm{EC}_{20}$ concentrations of GABA. $a$, Isoflurane and halothane enhance responses to GABA in wild-type $\alpha 2 \beta 1 \mathrm{GABA}_{\mathrm{A}}$ receptors. $b$, In mutant $\alpha 2(\mathrm{~S} 270 \mathrm{H}) \beta 1$ receptors, the enhancing effect of isoflurane is absent, whereas the halothane effect is preserved. $c$, In mutant $\alpha 2(\mathrm{~L} 232 \mathrm{~F}) \beta 1$ receptors, the enhancing effect of halothane is absent, whereas the isoflurane effect is preserved. $d$, In mutant $\alpha 2(\mathrm{~S} 270 \mathrm{~W}) \beta 1$ receptors, neither halothane nor isoflurane enhances GABA responses. $e$, Effects of chloroform on wild-type and mutant $\mathrm{GABA}_{\mathrm{A}}$ receptors. Chloroform potentiated the actions of GABA in wildtype $\alpha 2 \beta 1 \mathrm{GABA}_{\mathrm{A}}$ receptors, and this effect was preserved in mutant $\alpha 2$ (S270W) $\beta 1$ receptors but abolished in the double mutant $\alpha 2$ (S270W; A291W) $\beta 1$ receptor. The anesthetic concentrations used in the figures were as follows: isoflurane, $0.5 \mathrm{~mm}$; halothane, $0.32 \mathrm{~mm}$; and chloroform, $0.9 \mathrm{~mm}$. Calibration: $50 \mathrm{pA}$ (vertical axis), $10 \mathrm{sec}$ (horizontal axis).

to potentiation by both halothane $(-1.5 \pm 4.8 \% ; n=20$ cells $)$ and isoflurane $(5.8 \pm 4.6 \% ; n=20$ cells $)$.

\section{Anesthetics of dissimilar size have different cutoffs}

The isoflurane sensitivity of the $\mathrm{GABA}_{\mathrm{A}}$ receptor appears to show a cutoff effect when the receptor is mutated to increase the size of the residue at $\alpha 270$ (Koltchine et al., 1999). Specifically, in the series of mutant receptors $\alpha 2(\mathrm{~S} 270 \mathrm{X}) \beta 1$, these receptors become insensitive to isoflurane (molecular volume $144 \AA^{3}$; Fig. $2 a$ ), because the volume of the side-chain is increased beyond the volume of threonine, i.e., after a change in volume $\delta \mathrm{V}>30 \AA^{3}$ (Fig. 2a). We repeated this analysis with the physically smaller anesthetics halothane (molecular volume $110 \AA^{3}$ ) and chloroform (molecular volume $90 \AA^{3}$ ), and in each case, a cutoff phenomenon was again observed. However, the cutoff occurred at larger side chain volumes than for isoflurane. For halothane this occurs between $\delta \mathrm{V}=100-140 \AA^{3}$ (Fig. $2 b$ ), whereas for chloroform the cutoff occurs between $\delta \mathrm{V}=240-280 \AA^{3}$ (Fig. 2c).

\section{DISCUSSION}

Multiple cutoffs suggest a common interaction site for three general anesthetics

We explain these experimental data by proposing that the sidechains at the key positions L232, S270, and A291 (in transmem- 

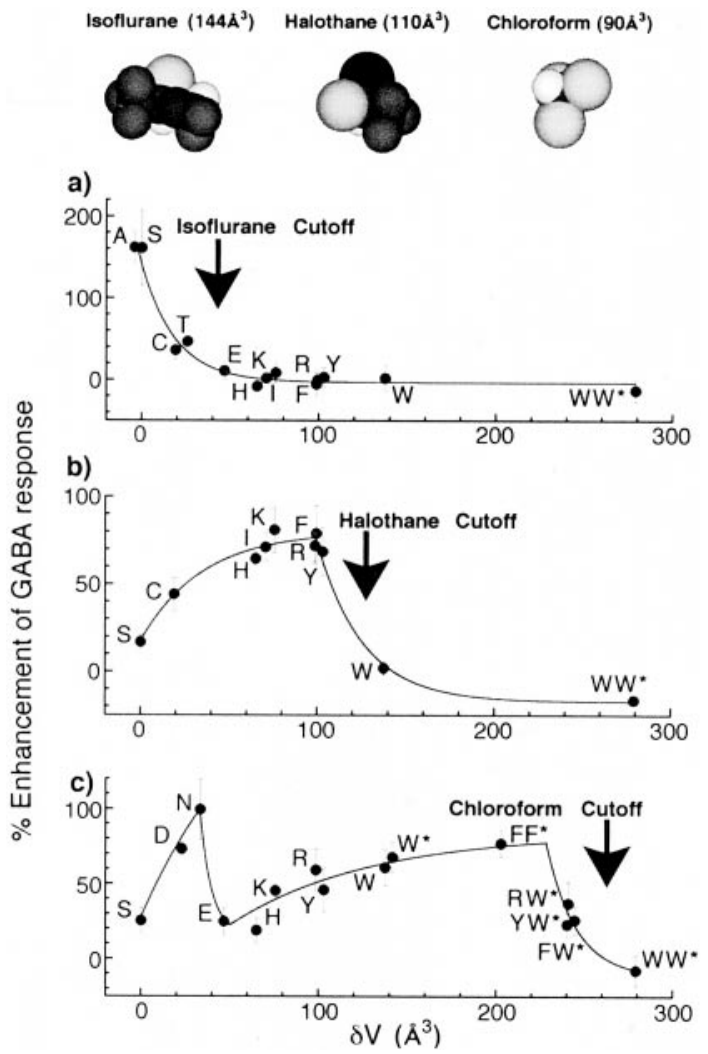

Figure 2. The effect of the addition of molecular volume by mutagenesis at positions 270 or 291 on $\mathrm{GABA}_{\mathrm{A}}$ receptor regulation by three anesthetics. Above the figure are representations of the molecular volumes of the three anesthetics. $a$, Addition of molecular volume produces a cutoff for isoflurane at $\partial V=30-40 \AA^{3}$. $b$, A cutoff is observed for halothane at $\partial V=140 \AA^{3}$. $c$, A cutoff for chloroform is not observed until $\partial V=$ $280 \AA^{3}$. The data for each anesthetic at each mutant receptor are expressed as the mean \pm SEM of the percentage enhancement (potentiation) of the current response to an $\mathrm{EC}_{20}$ concentration of GABA appropriate to that receptor, plotted against $\partial V$, the increase in molecular volume produced by mutagenesis.

brane segments TM1, TM2, and TM3, respectively, of the $\alpha$ subunit) define a binding cavity for small anesthetic molecules. Given our knowledge of the molecular volumes of the anesthetics and the cutoff data from our experiments, the volume of this hypothetical cavity can be estimated as between 250 and $370 \AA^{3}$. The introduction by mutagenesis of bulky side chains at the critical sites presumably decreases the molecular volume of the anesthetics that can be accommodated within such a cavity. It should be noted that these cutoff effects are independent of anesthetic concentration (Koltchine et al., 1999).

The present results highlight the importance of the TM domains for receptor activation and regulation; mutating selected residues in the TM1 (Thompson et al., 1999), TM2 (Koltchine et al., 1999), and TM3 (Krasowski and Harrison, 2000) domains often results in changes in $\mathrm{GABA} \mathrm{EC}_{50}$. These mutations also affect the sensitivity of the receptor to a variety of allosteric modulators. For example, in addition to the changes in anesthetic sensitivity reported here, a mutation in TM1 $\alpha 1$ (T230I) renders $\alpha 1^{*} \beta 3 \gamma 2$ s receptors more sensitive to the $\alpha 6$-specific noncompetitive antagonist furosemide; a similar result can be achieved by mutating (N265) in the $\beta 3$ subunit (Thompson et al., 1999).

Three additional features of the experimental data are noteworthy. First, the data for the $\mathrm{L} 232 \mathrm{~F}$ and $\mathrm{S} 270 \mathrm{H}$ mutants suggest that the anesthetics do not fit into the putative binding cavity in an identical manner; isoflurane (unlike halothane) is active at the L232F mutant receptor, whereas halothane (unlike isoflurane) is active at the $\mathrm{S} 270 \mathrm{H}$ mutant. This could be explained if halothane makes a closer contact with L232 than does isoflurane, which may instead lie closer to S270, accounting for the very sharp cutoff in Figure $2 a$. The loss of sensitivity to both isoflurane and halothane after additional volume is added in the L232W or S270W mutants supports this idea and suggests that these two residues are part of the same cavity. Second, whereas the ability of isoflurane to enhance GABA currents falls off drastically as side-chain volume is increased at the 270 position, from serine to phenylalanine, halothane actually increases in effectiveness as the residue at 270 is expanded, before reaching the cutoff point at tryptophan. It is possible that for halothane (unlike isoflurane), the binding interactions with TM2 may be suboptimal in the wild-type receptor and are actually improved by the addition of a bulky side chain at 270 . Finally, there is a marked discontinuity in the data for chloroform, at $\sim \partial V=40 \AA^{3}$. One explanation for this observation would be a change from a cavity occupied by two chloroform molecules in the Asn mutant to a singly occupied cavity in the Glu mutant. If a cavity of $>250 \AA^{3}$ does exist within the wild-type $\alpha$ subunit, it should be possible for two molecules of chloroform $\left(90 \AA^{3}\right)$ to bind simultaneously within such a cavity. There are existing precedents for double occupancy of cavities by general anesthetic molecules; for example, two molecules of halothane arranged in a head-tohead orientation are found within one of the anesthetic binding sites in human serum albumin (HSA) (Bhattacharya et al., 2000).

\section{Small cavities bind general anesthetic molecules}

Small cavities have been demonstrated to exist in a variety of globular proteins, both natural (Tilton et al., 1984; Eriksson et al., 1992; Kono et al., 2000) and synthetic (Johansson et al., 2000) in origin, and these can be altered in size and shape by mutagenesis of appropriate residues (Eriksson et al., 1992; Brunori et al., 2000; Kono et al., 2000; Lee et al., 2000). Anesthetics and other small gas molecules have been demonstrated to occupy such cavities, using a variety of techniques (Tilton et al., 1984; Franks et al., 1998; Brunori et al., 2000; Johansson et al., 2000). The binding of the anesthetic bromoform within a cavity in the enzyme firefly luciferase has been demonstrated using x-ray crystallography (Franks et al., 1998). Binding of such small ligands to protein cavities is often accompanied by the displacement of bound water molecules (Rashin et al., 1986; Matthews et al., 1995), and the interactions are further stabilized by low-energy $(\leq 2-4 \mathrm{kcal} / \mathrm{mol})$ van der Waals interactions with the cavity surface. The resulting free energy changes, although small, are commensurate with the relatively small energy changes associated with the gating of ligand-gated ion channels and are consistent with the low potencies for the anesthetic agents studied here $\left(10^{-4}-10^{-3} \mathrm{M}\right)$. More recently, Bhattacharya et al. (2000) have obtained the highresolution (2.4 $\AA$ ) structure of halothane bound to HSA. In all of these cases, anesthetic binding produced no change in local or global protein structure. Instead, the halothane molecules simply occupied pre-existing cavities and made contacts with small polar and apolar amino acids forming the cavity walls.

\section{An anesthetic binding cavity of defined volume in the $\mathrm{GABA}_{\mathrm{A}}$ receptor}

The existence of a similar cavity or "crevice" within the $\mathrm{GABA}_{\mathrm{A}}$ receptor is supported by data from scanning cysteine accessibility mutagenesis experiments on TM3 in the $\alpha$ subunit (Williams and 
Akabas, 1999). Moreover, recent experiments using cysteine substitutions in the transmembrane domain of the $\alpha$ subunit also indicate that Ser270 is likely to be involved in binding molecules such as ethanol and isoflurane. Mascia et al. (2000) showed that in the $\alpha 2$ (S270C) mutant, an alkanethiol anesthetic and the sulfhydryl reagent propyl methanethiosulfonate produced an irreversible enhancement of receptor function. Furthermore, once alkylated, the $\alpha 2(\mathrm{~S} 270 \mathrm{C})$ mutant was insensitive to isoflurane. These data suggest that $\alpha 2$ (S270) is indeed involved in the binding of these anesthetic molecules.

The cutoff data reported here predict that the receptor should be modulated by molecules larger than isoflurane. This is indeed the case; halogenated ether anesthetics (sevoflurane; $154 \AA^{3}$ ) and long-chain alcohols (decanol; 234 $\AA^{3}$ ) both potentiate $\mathrm{GABA}_{\mathrm{A}}$ receptor function (Dildy-Mayfield et al., 1996; Krasowski and Harrison, 2000). Interestingly, Ser270 is also critical for the action of alcohols (Mihic et al., 1997; Mascia et al., 2000) and so it is important to note that the cutoff for the actions of the $n$-alkanols on the $\mathrm{GABA}_{\mathrm{A}}$ receptor occur between decanol and dodecanol, i.e., somewhere between 234 and $276 \AA^{3}$ (Dildy-Mayfield et al., 1996); mutations at the homologous $\mathrm{I} 307$ residue in human GABA $\rho 1$ or the $\mathrm{S} 267$ residue in human GlyR $\alpha 1$ alter alcohol cutoff in these related receptors (Wick et al., 1998).

In conclusion, we suggest that modulation of $\mathrm{GABA}_{\mathrm{A}}$ receptor function by small general anesthetic molecules results from occupation of a cavity of volume $\sim 250-370 \AA^{3}$, the surface of which is partly defined by L232, S270, and A291. It is therefore of considerable interest that cutoff data from in vivo experiments also point to a maximal volume for anesthetic activity of $\sim 340 \AA^{3}$ (Curry et al., 1991).

\section{REFERENCES}

Bhattacharya AA, Curry S, Franks NP (2000) Binding of the General Anesthetics Propofol and Halothane to Human Serum Albumin. High resolution crystal structures. J Biol Chem 275:38731-38738.

Bragin A, Jando G, Nadasdy Z, Hetke J, Wise K, Buzsaki G (1995) Gamma $(40-100 \mathrm{~Hz})$ oscillation in the hippocampus of the behaving rat. J Neurosci 15:47-60.

Brunori M, Vallone B, Cutruzzola F, Travaglini-Allocatelli C, Berendzen J, Chu K, Sweet RM, Schlichting I. (2000) The role of cavities in protein dynamics: crystal structure of a photolytic intermediate of a mutant myoglobin. Proc Natl Acad Sci USA 97:2058-2063.

Curry S, Moss GWJ, Dickinson R, Lieb WR, Franks NP (1991) Probing the molecular dimensions of general anesthetic target sites in tadpoles (Xenopus laevis) and model systems using cycloalcohols. Br J Pharmacol 102:167-173.

Dildy-Mayfield JE, Mihic SJ, Liu Y, Deitrich RA, Harris RA (1996) Actions of long chain alcohols on $\mathrm{GABA}_{\mathrm{A}}$ and glutamate receptors: relation to in vivo effects. Br J Pharmacol 118:378-384.

Duncalfe LL, Carpenter MR, Smillie LB, Martin IL, Dunn SM (1996) The major site of photoaffinity labeling of the gamma-aminobutyric acid type A receptor by $[3 \mathrm{H}]$ flunitrazepam is histidine 102 of the alpha subunit. J Biol Chem 271:9209-9214.

Eriksson AE, Baase WA, Zhang X-J, Heinz DW, Blaber M, Baldwin EP, Matthews BW (1992) Response of a protein structure to cavity-creating mutations and its relation to the hydrophobic effect. Science 255:178-183.

Faulkner HJ, Traub RD, Whittington MA (1998) Disruption of synchronous gamma oscillations in the rat hippocampal slice: a common mechanism of anaesthetic drug action. Br J Pharmacol 125:483-492.

Franks NP, Lieb WR (1994) Molecular and cellular mechanisms of general anesthesia. Nature 367:607-614.

Franks NP, Jenkins A, Conti E, Lieb WR, Brick P (1998) Structural basis for the inhibition of firefly luciferase by a general anesthetic. Biophys J 75:2205-2211.

Greenblatt EP, Meng X (1999) A critical amino acid for halothane action. Anesthesiology 91:A807.

Harrison NL, Kugler JL, Jones MV, Greenblatt EP, Pritchett DB (1993) Positive modulation of human gamma-aminobutyric acid type A and glycine receptors by the inhalation anesthetic isoflurane. Mol Pharmacol 44:628-632.

Jefferys JG, Traub RD, Whittington MA (1996) Neuronal networks for induced " $40 \mathrm{~Hz}$ " rhythms. Trends Neurosci 19:202-208.
Jenkins A, Franks NP, Lieb WR (1999) Effects of temperature and volatile anesthetics on GABA(A) receptors. Anesthesiology 90:484-491.

Johansson JS, Scharf D, Davies LA, Reddy KS, Eckenhoff RG (2000) A designed four- $\alpha$-helix bundle that binds the volatile general anesthetic halothane with high affinity. Biophys J 78:982-993.

Jones MV, Harrison NL (1993) Effects of volatile anesthetics on the kinetics of inhibitory postsynaptic currents in cultured rat hippocampal neurons. J Neurophysiol 70:1339-1349.

Koltchine VV, Finn SE, Jenkins A, Nikolaeva N, Lin A, Harrison NL (1999) Agonist gating and isoflurane potentiation in the human $\mathrm{GABA}_{\mathrm{A}}$ receptor determined by the volume of a TM2 residue. Mol Pharmacol 56:1087-1093.

Kono H, Saito M, Sarai A (2000) Stability analysis for the cavity-filling mutations of the Myb DNA-binding domain utilizing free-energy calculations. Proteins 38:197-209.

Krasowski MD, Harrison NL (2000) The actions of ether, alcohol and alkane general anaesthetics on GABAA and glycine receptors and the effects of TM2 and TM3 mutations. Br J Pharmacol 129:731-743.

Krasowski MD, Koltchine VV, Rick CEM, Ye Q, Finn SE, Harrison NL (1998) Propofol and other intravenous anesthetics have sites of action on the $\gamma$-aminobutyric acid-A receptor distinct from that for isoflurane. Mol Pharmacol 53:530-538.

Lee J, Lee K, Shin S (2000) Theoretical studies of the response of a protein structure to cavity-creating mutations. Biophys J 78:1665-1671.

$\mathrm{Li}$ X, Pearce RA (2000) Effects of halothane on GABA(A) receptor kinetics: evidence for slowed agonist unbinding. J Neurosci 20:899-907.

Mascia M-P, Trudell JR, Harris RA (2000) Specific binding sites for alcohols and anesthetics on ligand-gated ion channels. Proc Natl Acad Sci USA 97:9305-9310.

Matthews BW, Morton AG, Dahlquist FW (1995) Use of NMR to detect water within nonpolar protein cavities. Science 270:1847-1849.

McKernan RM, Rosahl TW, Reynolds DS, Sur C, Wafford KA, Atack JR, Farrar S, Myers J, Cook G, Ferris P, Garrett L, Bristow L, Marshall G, Macaulay A, Brown N, Howell O, Moore KW, Carling RW, Street LJ, Castro JL, Ragan CI, Dawson GR, Whiting PJ (2000) Sedative but not anxiolytic properties of benzodiazepines are mediated by the $\mathrm{GABA}_{\mathrm{A}}$ receptor $\alpha 1$ subtype. Nat Neurosci 3:587-592.

Mihic SJ, Ye Q, Wick MJ, Koltchine VV, Krasowski MD, Finn SE, Mascia MP, Valenzuela CF, Hanson KK, Greenblatt EP, Harris RA, Harrison NL (1997) Sites of alcohol and volatile anesthetic action on $\mathrm{GABA}_{\mathrm{A}}$ and glycine receptors. Nature 389:385-389.

Nakahiro M, Yeh JZ, Brunner E, Narahashi T (1989) General anesthetics modulate GABA receptor channel complex in rat dorsal root ganglion neurons. FASEB J 3:1850-1854.

Nishikawa K, MacIver MB (2000) Membrane and synaptic actions of halothane on rat hippocampal pyramidal neurons and inhibitory interneurons. J Neurosci 20:5915-5923.

Rampil IJ (1998) A primer for EEG signal processing in anesthesia. Anesthesiology 89:980-1002.

Rashin AA, Iofin M, Honig B (1986) Internal cavities and buried waters in globular proteins. Biochemistry 25:3619-3625.

Rudolph U, Crestani F, Benke D, Brünig I, Benson JA, Fritschy J-M, Martin JM, Bluethmann H, Möhler H (1999) Benzodiazepine actions mediated by specific $\gamma$-aminobutyric acid receptor subtypes. Nature 401:796-800.

Sanna E, Garau F, Harris RA (1995) Novel properties of homomeric $\beta 1$ $\gamma$-aminobutyric acid type A receptors: actions of the anesthetics propofol and pentobarbital. Mol Pharamacol 47:213-217.

Thompson SA, Arden SA, Marshall G, Wingrove PB, Whiting PJ, Wafford KA (1999) Residues in transmembrane domains I and II determine $\gamma$-aminobutyric acid type $\mathrm{A}_{\mathrm{A}}$ receptor subtype-selective antagonism by furosemide. Mol Pharmacol 55:993-999.

Tilton Jr RF, Kuntz Jr ID, Petsko GA (1984) Cavities in proteins: structure of a metmyoglobin-xenon complex solved to $19 \AA$ A Biochemistry 23:2849-2857.

Wakamori M, Ikemoto Y, Akaike N (1991) Effects of two volatile anesthetics and a volatile convulsant on the excitatory and inhibitory amino acid responses in dissociated CNS neurons of the rat. J Neurophysiol 66:2014-2021.

Whittington MA, Traub RD, Jefferys JG (1995) Synchronized oscillations in interneuron networks driven by metabotropic glutamate receptor activation. Nature 373:612-615.

Whittington MA, Jefferys JG, Traub RD (1996) Effects of intravenous anaesthetic agents on fast inhibitory oscillations in the rat hippocampus in vitro. Br J Pharmacol 118:1977-1986.

Wick MJ, Mihic SJ, Ueno S, Mascia MP, Trudell JR, Brozowski SJ, Ye Q, Harrison NL, Harris RA (1998) Mutations of gamma-aminobutyric acid and glycine receptors change alcohol cutoff: evidence for an alcohol receptor? Proc Natl Acad Sci USA:95:6504-6509.

Williams DB, Akabas MH (1999) GABA increases the water-accessibility of M3 membrane-spanning residues in GABA-A receptors. Biophys J 77:99037-99037. 